\title{
歯車形軸継手の歯当たり及び軸角変動用歯面隙間*
}

\author{
箱 崎 義 英*1, 島 地 重 幸*1

\section{Contact Tooth Bearing and Tooth Gap for Shaft Angle Fluctuation on Gear Coupling}

\author{
Yoshihide HAKOZAKI*2 and Shigeyuki SHIMACHI \\ *2 Department of Mechanical Engineering, Iwate University, \\ 4-3-5 Ueda, Morioka-shi. Iwate, (220-8551 Japan
}

\begin{abstract}
Recent demands of the gear coupling are to reduce gear noise that is supposed to be caused by gear tooth gap for shaft angle fluctuation. In generally, large shaft angle increases tooth gap for shaft angle fluctuation. On the same time, load capacity is supposed to decrease. The tooth gap for shaft angle fluctuation is given by the analysis of tooth contact. The conventional analysis is an approximate one and is limited on its precision. An analysis of higher precision is necessary for recent critical demands on the gear coupling. This paper discusses analysis of clearance of matching tooth surface, where the profile of rack tooth surface has a straight line. Conact bearing pattern spreads in the direction to tooth tip and has edge contact. Those are different from the conventional assumptions.
\end{abstract}

Key Words: Machine Element, Gear, Coupling, Tooth Gap, Contact Tooth Number

\section{1. 緒言}

電気車の電動機軸と車輪駆動軸との間には, 歯車形 軸継手が用いられている。この歯車形軸継手は，一般 にインボリュート歯形を持つ円筒形内歯車と樽形外歯 車とで構成されている. 軸角変動の片側幅は $5^{\circ}$ 前後 であるが，近年，さらに大きい軸角に対応できるもの が望まれている.

歯車形軸継手で軸角を変動させるためには, 軸角ゼ 口位置においてバックラッシに相当する歯面隙間（以 下，軸角変動用歯面隙間と呼ぶ）を与えておく必要が ある．軸角を大きくするほど, この軸角変動用歯面隙 間を大きくする必要がある。しかし，これが大きくな ると電気車では振動や騒音が大きくなるため, 軸角変 動用歯面隙間を出来るだけ小さく設計することになる. 現状では, 軸角変動に対して必要な軸角変動用歯面隙 間の量は, 解析的に正確に求められていない.

軸角の大きい継手を設計するとき，もう一つの課題 がある．軸角ゼロでのかみ合い歯数は多いが，軸角が 大きくなると急激にかみ合い歯数が少なくなり，負荷 能力の減少が心配される. 歯車形軸継手歯車の形状解 析と負荷能力評価については，高井ら(1)の報告がある が，それは，当時の一般的な手法である近似解析によ

\footnotetext{
* 原稿受付 2003 年 9 月 29 日.

*1 正員, 岩手大学工学部 (五020-8551 盛岡市上田 4-3-5).

E-mail : hako@ iwate-u.ac.jp
}

るものである.

このように，近年の軸角変動幅の増大一の要求に伴 う, 負荷能力向上と振動騒音低減に対応するためには, 諸仮定に基づく従来の近似的解析では不十分であり, 歯車の歯面隙間状況を精度良く解析寸ることが必要と なっている.

本報告は, 汎用されている形状の歯車形軸継手歯車 対, 寸なわち, 歯面の含軸断面が円弧の樽形外歯車と インボリュート歯形を持つ円筒形内歯車について, 接 触歯面隙間 (歯当たり) および軸角変動用歯面隙間の解 析結果を報告する.さらに，この歯車の歯面対は運動 学的には点接触するが, 解析結果を検証するため, 歯 面の点接触位置と軸角との関係を求めた結果について も述べる.

\section{2. 接触歯面隙間の解析}

図 1 に円筒形内歯車と樽形外歯車から成る歯車形軸 継手を示す. 円筒形内歯車は, インボリュート歯形の すぐ歯を持つものとする. また，樽形外歯車は，その 含軸断面内の円弧をトレースするようにホブ工具を移 動させて製作されるものとする. 樽形外歯車の解析で は,一般に行われるように，ホブ工具の移動によって 歯すじが円弧であるラックが作られるとして解析する.

$2 \cdot 1$ 接触雪面隙間と歯当たり 点接触歯面に負 荷をかけると, 弾性変形（いわゆるへルツ変形）によ 


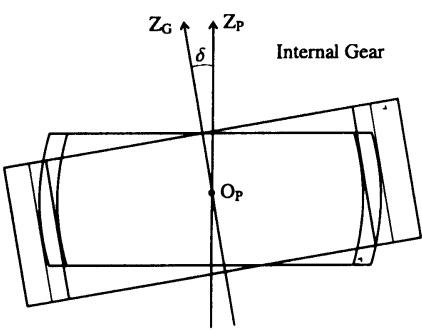

External Gear

Fig. 1 Gear coupling

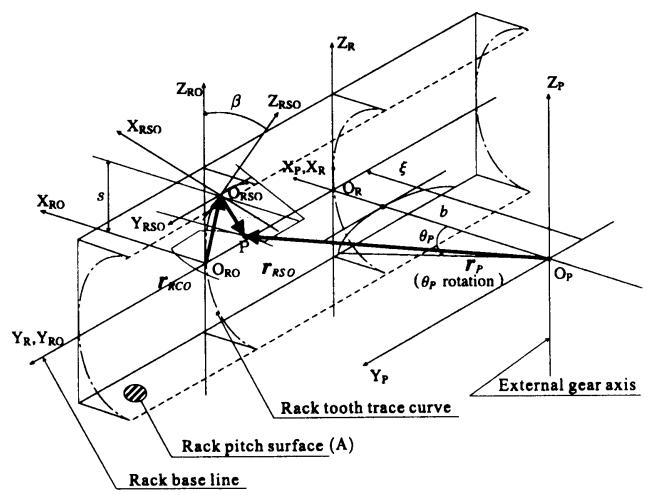

Fig. 2 External gear and rack

り，接触点近傍に広がる面で歯面同士は接触する．接 触しあうこの面の広がりを歯当たりと呼ぶなら，歯当 たりは, 負荷の大きさ, 歯面の相対曲率で代表される 歯面間隙間, 歯先・歯元の歯面の広がり限界などによっ て決まる.一般的には, 単位負荷に対するこの歯当た り面積が広いほど, 歯面の面圧強度についての負荷能 力は高くなるので, 歯面の負荷能力を評価する目安と なる.

ところで, 一般的な歯面同士の接触を近似する際に 用いられる平面と棈球面の接触について考えると, 弾 性変形により接触しあう面の広がり形状と, 平面と楕 球面の等隙間曲線に囲まれる広がりの形状は, 必ずし も一致しない. しかし, 両者は大略的には似ている.

そこで，本考察では，接触歯面間隙間の等隙間曲線 に囲まれる面の広がりを便宜上“歯当たり”と呼ぶこ とにする.

2.2 ラックの㐘面 図 2 に継手の外歯車とこれ を創成するラックの関係を示す，同図において，継手 の外歯車軸を $\mathrm{Z}_{\mathrm{p}}$, その上に原点 $\mathrm{O}_{\mathrm{p}}$ を置いた座標系を 定める.

$\mathrm{O}_{\mathrm{p}}-\mathrm{X}_{\mathrm{p}} \mathrm{Y}_{\mathrm{p}} \mathrm{Z}_{\mathrm{p}}$ : 空間に固定した座標系

座標軸 $X_{\mathrm{p}}$ に垂直な平面と，軸線 $\mathrm{Y}_{\mathrm{R}}$ で接触し，し かもその母線が外歯車軸に直角な方向になるような筒

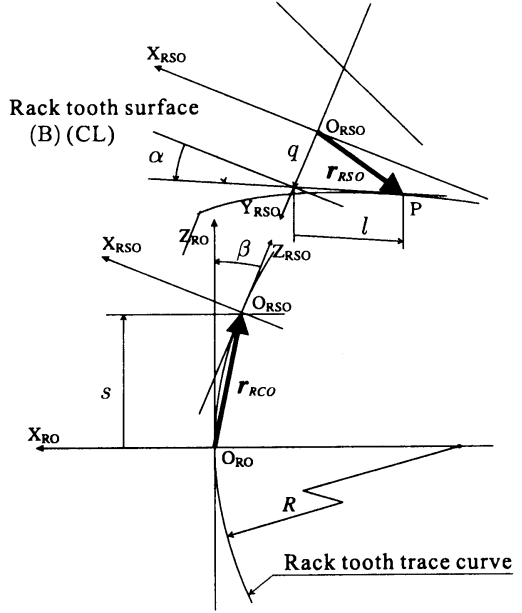

Fig. 3 Rack tooth surface

面 $\mathrm{A}$ を考える．また，その母線に直角な方向に歯すじ 線を持ち，しかも歯すじ線に直角な断面の形状が標準 ラック形状となるような歯面 $\mathrm{B}$ を考え, 筒面 $\mathrm{A}$ に固着 する. そして,この歯面Bを外歯車創成用のラック歯 面，筒面 $A$ を筒面ラックのピッチ面，軸線 $Y_{\mathrm{R}}$ をラッ クの基準線と呼ぶことにする。 また，図 2 に示すよう に, $b$ を外歯車歯切りピッチ円半径, $\xi$ を転位量と才 る.さらに, 座標軸 $X_{\mathrm{P}}$ と軸線 $\mathrm{Y}_{\mathrm{R}}$ の交点 $\mathrm{O}_{\mathrm{R}}$ を原点と する次の座標系を定める。

$\mathrm{O}_{\mathrm{R}}-\mathrm{X}_{\mathrm{R}} \mathrm{Y}_{\mathrm{R}} Z_{\mathrm{R}}$ : 空間に固定した座標系

外歯車が $\theta_{P}$ 回転したとき原点 $\mathrm{O}_{\mathrm{R}}$ にあったラック上 の点は,・ピッチ線に沿って点 $\mathrm{O}_{R O}$ まで移動する. ラッ ク自体に固定した座標系も定めることにする。

$\mathrm{O}_{\mathrm{RO}}-\mathrm{X}_{\mathrm{RO}} \mathrm{Y}_{\mathrm{RO}} \mathrm{Z}_{\mathrm{RO}}$ : ラックに固定した座標系

また, 各座標軸方向の単位べクトルを $i, j, k$ とする.

ラックの基準線に垂直な平面によるラック面の断面 及びラック歯すじ曲線に垂直な平面によるラック面の 断面を図 3 に示す. 同図において，ラック歯形上の点 Pを表すため諸量を次のように定める.

$\mathrm{O}_{\mathrm{RSO} O}-\mathrm{X}_{\mathrm{RSO}} \mathrm{Y}_{\mathrm{RSO}} \mathrm{Z}_{\mathrm{RSO}}$ ：歯すじに固定した座標系

$R:$ 円弧歯すじ曲率半径

$\beta:$ 歯すじ接線と $\mathrm{Z}_{\mathrm{RO}}$ の成す角

$\alpha$ : ラック歯面圧力角

$q:$ ラック歯形直線の位置

$l:$ ラック歯形方向に測った点 $\mathrm{P}$ の位置

$\theta_{P}:$ 創成のために回転する外歯車の回転角

とする．また，点 $\mathrm{P}$ は創成運動として回転する外歯車 の回転角が $\theta_{P}$ であるときのラック歯形と外歯車の接 触点である。

ラックの歯すじ曲線上の点 $\mathrm{O}_{\mathrm{RSO}}$ の位置を表すパラ 
メータを $s$ とする. $s$ を座標 $\mathrm{Z}_{\mathrm{RO}}$ の值, $x$ を座標 $\mathrm{X}_{\mathrm{RO}}$ の 值と寸る. $s$ での $x$ および点 $(s, x)$ での傾き角 $\beta$ は

$$
\begin{gathered}
x=-R+\sqrt{R^{2}-s^{2}} \\
\beta=\tan ^{-1}(-s /(R-x))
\end{gathered}
$$

で与えられる．従ってラックの歯すじ曲線を表す位置 ベクトル $\boldsymbol{r}_{R C O}$ は次式で表される.

$$
\boldsymbol{r}_{R C O}=x \boldsymbol{i}+s \boldsymbol{k}
$$

座標 $\mathrm{O}_{\mathrm{RSO}}-\mathrm{X}_{\mathrm{RSO}} \mathrm{Y}_{\mathrm{RSO}} \mathrm{Z}_{\mathrm{RSO}}$ 系内でラック歯面を表す位置 ベクトル $\boldsymbol{r}_{R S O}$ は

$$
\boldsymbol{r}_{\text {RSO }}=-l \cos \alpha \boldsymbol{i}+(q-l \sin \alpha) \boldsymbol{j}
$$

となる.

ラック歯形上の点 $\mathrm{P}$ は次式で表される.

$$
\overrightarrow{\mathrm{O}_{\mathrm{P}} \mathrm{P}}=\overrightarrow{\mathrm{O}_{\mathrm{P}} \mathrm{O}_{\mathrm{R}}}+b \theta_{P} \boldsymbol{j}+\boldsymbol{r}_{R C O}+\mathrm{R}(\boldsymbol{j}, \beta) \boldsymbol{r}_{k S O}
$$

但し， $\overrightarrow{\mathrm{O}_{\mathrm{P}} \mathrm{O}_{\mathrm{R}}}=(b+\xi) \boldsymbol{i}$ ，また記法 $\mathrm{R}(\boldsymbol{a}, \theta) \boldsymbol{b}$ は，任意の ベクトル $\boldsymbol{b}$ を単位ベクトル $\boldsymbol{a}$ の回りに任意の角 $\theta$ だけ 回転させたときのべクトル $c$ を表す。ベクトル $c$ は

$$
\boldsymbol{c}=(\boldsymbol{b} \cdot \boldsymbol{a}) \boldsymbol{a}+\{\boldsymbol{b}-(\boldsymbol{b} \cdot \boldsymbol{a}) \boldsymbol{a}\} \cos \theta+(\boldsymbol{a} \times \boldsymbol{b}) \sin \theta
$$

\section{で表される.}

ラック歯面は, 歯すじ線上の位置を表すパラメータ $s$ と歯形直線上の位置を表すパラメータ $l$ のつで表 されたことになる.

$2 \cdot 3$ ラックと外歯車の接触の条件 図 4 にラッ クの歯すじ曲線上の点 $\mathrm{O}_{\mathrm{RSO}}$ を通り，歯すじ線に垂直な 平面内で, ラック歯形と接触点及び外歯車とうックの 運動学的転がりピッチ点を示す．外歯車の転がりピッ チ円筒とラックの転がりピッチ平面とが転がり接触す る点を $\mathrm{C}_{\mathrm{N}}$ とする. ラック歯面の法線は常に, 歯すじ 線に垂直な平面内にあり, 歯面法線は運動学的ピッチ 点 $\mathrm{C}_{\mathrm{N}}$ を通る. 従って歯面上の点 $\mathrm{P}$ の位置 $l$ は次式で 与えられる。

$$
l=\left(b \theta_{P}+q\right) \sin \alpha+\left\{\xi+\left(\boldsymbol{i} \cdot \boldsymbol{r}_{\left.R C_{0}\right)}\right)\right\} \cos \alpha / \cos \beta
$$

\section{4 基準回転位置における外歯車歯面 創成運} 動として回転する外歯車の回転角が $\theta_{P}$ であるときの ラックと外歯車の接触点 $\mathrm{P}$ が分かったので, 外歯車が 回転しない基準回転位置での外歯車の歯面は,

$$
\overrightarrow{\mathrm{O}_{\mathrm{PO}} \mathrm{P}}=\mathrm{R}\left(\boldsymbol{k},-\theta_{\mathrm{P}}\right) \overrightarrow{\mathrm{O}_{\mathrm{P}} \mathrm{P}}
$$

で表される. パラメータlを与えると式(7)から $\theta_{P}$ が 求まるので, 外歯車歯面はパラメータlとパラメータ $s$ によって表されたことになる.

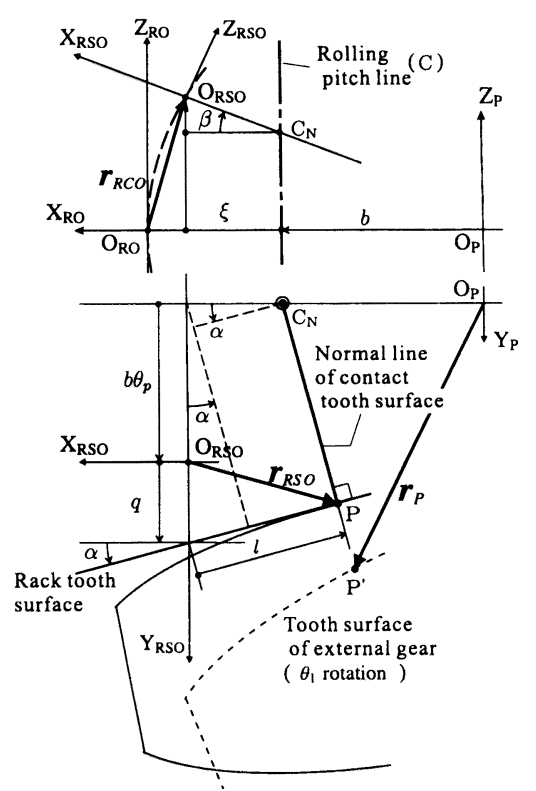

Fig. 4 Contact point on the rack tooth profile

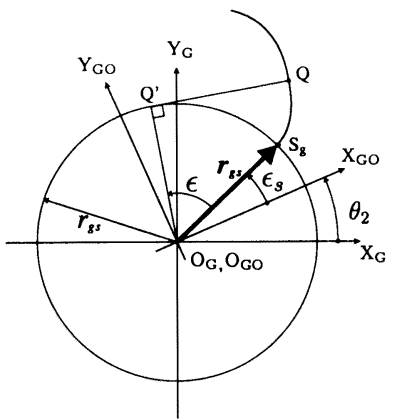

Fig. 5 Involute tooth profile of internal gear

この外歯車を軸回りに角 $\theta_{1}$ 回転した外歯車の歯面 上の点 $\mathrm{P}^{\prime}$ の位置は

$$
\boldsymbol{r}_{\boldsymbol{r}}=\mathrm{R}\left(\boldsymbol{k},-\theta_{P}+\theta_{1}\right) \overrightarrow{\mathrm{O}_{\mathrm{P}} \mathrm{P}}
$$

で表される.このベクトル $\boldsymbol{r}_{r}$ は, 外歯車が回転しな い基準位置から $\theta_{1}$ 回転したときの外歯車歯面を表市 位置ベクトルである.

2.5 内柬車歯面 図 5 に内歯車軸に垂直な断面内 での, 内歯車に固定した座標系におけるインボリュー 卜歯形を持つ内歯車歯面を示す.

$\mathrm{O}_{\mathrm{G}}-\mathrm{X}_{\mathrm{G}} \mathrm{Y}_{\mathrm{G}} \mathrm{Z}_{\mathrm{G}}$ : 空間に固定した座標系

$\mathrm{O}_{(\mathrm{i})}-\mathrm{X}_{\mathrm{Ci})} \mathrm{Y}_{(\mathrm{i})} \mathrm{Z}_{(\mathrm{i})}$ : 内歯車に固定した座標系

$r_{g s:}:$ 内歯車の基礎円半径

$\epsilon_{s}: \mathrm{X}_{(\mathrm{i})}$ 軸からインボリュート曲線の始点 $\mathrm{S}_{\sharp}$ までの 角度 


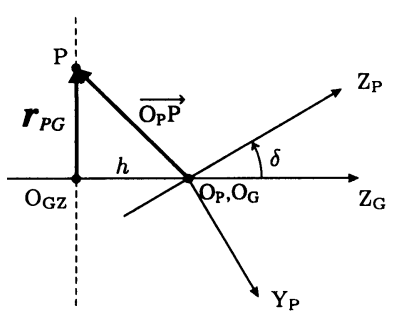

Fig. 6 External gear reference frame and internal gear reference frame

$\epsilon$ :インボリュート曲線上の点 $\mathrm{Q}$ を表すパラメータ $\theta_{2}:$ 内歯車の回転角

$r_{g s}$ : 内歯車が $\theta_{2}$ 回転した位置で, 軸 $\mathrm{Z}_{\mathrm{CO} \mathrm{O}}$ からインボ リュート始点 $\mathrm{S}_{\mathrm{g}}$ に向かうべクトル

軸 $\mathrm{Z}_{\mathrm{GO}}$ からインボリュート始点に向かうベクトル $\boldsymbol{r}_{s,}$ を与えることと, 内歯車の回転角 $\theta_{2}$ を与えることは同 じことである. その内歯車歯面のインボリュート曲線 の始点を表す位置ベクトル $\boldsymbol{r}_{s s}$ は次のように表される。

$$
\boldsymbol{r}_{s s}=r_{s s}\left\{\cos \left(\epsilon_{s}+\theta_{2}\right) \boldsymbol{i}+\sin \left(\epsilon_{s}+\theta_{2}\right) \boldsymbol{j}\right\}
$$

内歯車歯面上の点 $\mathrm{Q}$ の位置は歯形パラメータ $\epsilon$ を用 い, 次式で与えられる.

$$
\begin{gathered}
\overrightarrow{\mathrm{O}_{\mathrm{G}} \mathrm{Q}^{\prime}}=\mathrm{R}(\boldsymbol{k}, \epsilon) \boldsymbol{r}_{g s} \\
\overrightarrow{\mathrm{Q}^{\prime} \mathrm{Q}}=\epsilon \mathrm{R}(\boldsymbol{k},-\pi / 2) \overrightarrow{\mathrm{O}_{\mathrm{G}} \mathrm{Q}^{\prime}} \\
\overrightarrow{\mathrm{O}_{\mathrm{G}} \mathrm{Q}}=\overrightarrow{\mathrm{O}_{\mathrm{G}} \mathrm{Q}^{\prime}}+\overrightarrow{\mathrm{Q}^{\prime} \mathrm{Q}}
\end{gathered}
$$

2.6 外歯車歯面と内歯車歯面の隙間 $\Delta$ 図 6 に 外歯車座標系 $\mathrm{O}_{\mathrm{p}}-\mathrm{X}_{\mathrm{p}} \mathrm{Y}_{\mathrm{p}} \mathrm{Z}_{\mathrm{p}}$, と内歯車座標系 $\mathrm{O}_{\mathrm{i}}-\mathrm{X}_{\mathrm{G}} \mathrm{Y}_{\mathrm{G}} \mathrm{Z}_{\mathrm{G}}$ を示す. 外歯車軸 $\mathrm{Z}_{\mathrm{p}}$, と内歯車軸 $\mathrm{Z}_{\mathrm{i}}$ が軸角 $\delta$ で交わる ものとする．また軸 $\mathrm{X}_{\mathrm{p}}$ と軸 $\mathrm{X}_{\mathrm{O}}$ は一致しているもの とする.

内歯車座標系で見た外歯車歯面上の点 $\mathrm{P}$ は

$$
\mathrm{R}(\boldsymbol{i}, \delta) \boldsymbol{r}_{r}
$$

であり, 外歯車歯面を表す位置ベクトル $\boldsymbol{r}_{\boldsymbol{r}}$, の内歯車 座標系への射影を表すべクトル $\boldsymbol{r}_{P G}$ は

$$
\boldsymbol{r}_{P G}=\mathbf{R}(\boldsymbol{i}, \delta) \boldsymbol{r}_{P}-\boldsymbol{k}\left\{\boldsymbol{k} \cdot \mathrm{R}(\boldsymbol{i}, \delta) \boldsymbol{r}_{p}\right\}
$$

となる. また，歯車軸の交点 $\mathrm{O}_{\mathrm{p}}, \mathrm{O}_{\mathrm{G}}$ からこの平面ま での距離を $h$ とすると

$$
h=\left\{\boldsymbol{k} \cdot \mathbf{R}(\boldsymbol{i}, \delta) \boldsymbol{r}_{p}\right\}
$$

となる.

図7において, 内歯車軸に垂直な平面内で点 $\mathrm{P}$ から 内歯車歯面におろした垂線の足を $\mathrm{Q}$, その垂線が内歯

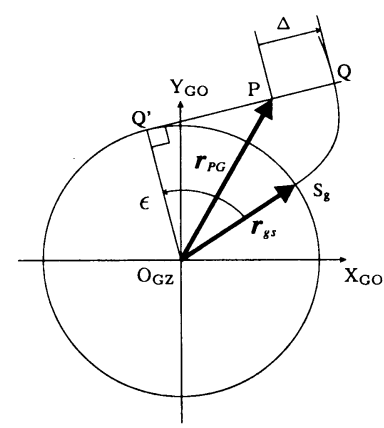

Fig. 7 Distance from external gear tooth surface to internal gear tooth surface

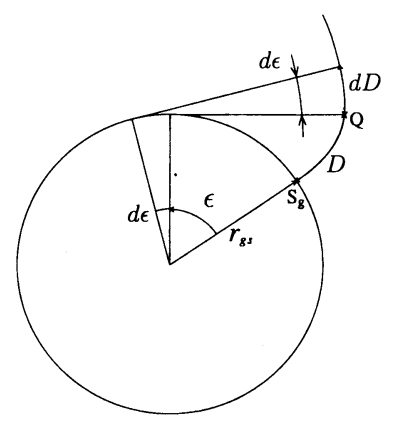

Fig. 8 Length along the involute curve

車の基礎円に接する点を $\mathrm{Q}^{\prime}$ とする.内歯車軸との交 点 $\mathrm{O}_{\mathrm{GZ}}$ からインボリュート曲線の始点 $\mathrm{S}_{\mathrm{g}}$ に向かうべ クトル $\boldsymbol{r}_{g s}$ を角度 $\epsilon$ 回転させると接点 $\mathrm{Q}^{\prime}$ に向かうべク トルになるが, このベクトルとベクトル $\overrightarrow{\mathrm{Q}^{\prime} \mathrm{P}}$ は直交す るから，

$$
\left(\overrightarrow{\mathrm{Q}^{\prime} \mathrm{P}} \cdot \overrightarrow{\mathrm{O}_{\mathrm{Gi} /} \mathrm{Q}^{\prime}}\right)=\left\{\left(\boldsymbol{r}_{P^{\prime}(}-\mathrm{R}(\boldsymbol{k}, \boldsymbol{\epsilon}) \boldsymbol{r}_{k s}\right) \cdot \mathrm{R}(\boldsymbol{k}, \boldsymbol{\epsilon}) \boldsymbol{r}_{k s}\right\}=0
$$

が得られる.この式を変形し，

$$
\left\{\boldsymbol{r}_{p^{\prime}(} \cdot \mathrm{R}(\boldsymbol{k}, \epsilon) \boldsymbol{r}_{s, s}\right\}=\boldsymbol{r}_{s: s}^{2}
$$

が得られる. ベクトルの回転についての演算子式 (6) を適用し，

$$
\left(\boldsymbol{r}_{P G} \cdot \boldsymbol{k} \times \boldsymbol{r}_{g s}\right) \sin \epsilon+\left(\boldsymbol{r}_{P G} \cdot \boldsymbol{r}_{g s}\right) \cos \epsilon-\boldsymbol{r}_{g s}^{2}=0
$$

を得る。この式は

$$
A \sin \epsilon+B \cos \epsilon+C=0
$$

の形を持ちっこれを満たす $\epsilon$ は

$$
\tan \epsilon / 2=\left(-A \pm \sqrt{A^{2}+B^{2}-C^{2}}\right) /(C-B)
$$


となるが， $\epsilon>0$ となるように複号を選んで，歯面の 隙間 $\Delta$ は

$$
\Delta=\overrightarrow{\mathrm{QQ}^{\prime}}-\overrightarrow{\mathrm{PQ}^{\prime}}=\epsilon \boldsymbol{r}_{g^{s}}-\sqrt{\left\{\boldsymbol{r}_{P G}-\mathrm{R}(\boldsymbol{k}, \epsilon) \boldsymbol{r}_{g .}\right\}^{2}}
$$

で求められる.

内歯車歯面上で隙間 $\Delta$ を表示するため, 点 $\mathrm{Q}$ の位 置を求めておくことにする. 点 $\mathrm{Q}$ の内歯車軸方向の位 置は $h$ で与えられている。 これと直交する方向，寸な わち内歯車のインボリュートの起点 $\mathrm{S}_{\mathrm{g}}$ から歯形曲線 に沿って測定すると, 図 8 に示すように, 点 $\mathrm{Q}$ までの 距離 $D$ は, $d D=\boldsymbol{r}_{g s} \in d \epsilon$ を積分して,

$$
D=\boldsymbol{r}_{g^{s}} \epsilon^{2} / 2
$$

である。

外歯車の歯面上の点 $\mathrm{P}$ を表すパラメータは $l, s$ で あり，その回転角は $\theta_{1}$ である。 また，内歯車の回転 角は $\theta_{2}$ であり，これらは任意に与えることが出来る。 これらを与えれば, 点 $\mathrm{P}$ から内歯車歯面上に下ろした 垂線の足 $\mathrm{Q}$ の位置はパラメータ $h, D$ で表され，その 点での隙間 $\Delta$ が得られる.

\section{3. 歯車の接触状況}

3.1 $5 \mu \mathrm{m}$ 歯当たりと $5 \mu \mathrm{m}$ 歯当たり面積 $A_{c}$ 歯 面接触における弾性変形の程度や光明丹による歯当た り検査などを念頭に㯰き, あくまで, 参考までに, 切 りの良い数值として $5 \mu \mathrm{m}$ の隙間を定め, 接触点近傍 での歯面隙間が $5 \mu \mathrm{m}$ 以下の部分, 寸なわち, 等隙間值 が $5 \mu \mathrm{m}$ の歯当たりを“5 $5 \mu \mathrm{m}$ 歯当たり”と呼ぶことにす る. また, 接触点近傍の歯面隙閒が $5 \mu \mathrm{m}$ 以下となる計 算点に対して, 内歯車歯面上での上下左右の間隔 $\delta h$, $\delta D$ から微小面積を求め, それらを歯車全周に対して 累積することで “5 $\mu \mathrm{m}$ 歯当たり面積 $A_{c}$ ”を算定する.

3.2 かみ合い歯数 $Z_{c}$ 剛体の菊面同士は点で接 触し, 歯面の広がり内にある同時接触点の個数を計算 できる、しかし, 現実の歯面は弾性変形のため接触し ている、これを無視することは出来ない，そこで，目 安を得ると言う意味で， $5 \mu \mathrm{m}$ 歯当たりを持つ歯面対の 個数を累積し “5 $\mu \mathrm{m}$ かみあい歯数 $Z_{c}$ ”とする.

$3 \cdot 3$ 軸角変動用歯面隙間量 $C_{n}$ 歯車形軸接手で は, 軸角 $\delta$ を与えたとき歯面が接触する場所は, 両車 軸の共通法線の近傍で点接触する.

軸角 $\delta$ がゼロの位置で接触しあっているものとす る.この歯車相対回転位置を保持したまま, 軸角を $\delta$ とすると, 両車軸の共通法線の近傍にある菌面同士は 食い込みあい, $\Delta$ は負の值として求まる.内歯車菌面 はインボリュート曲面である. その平行曲面もインボ
Table 1 Main dimensions of example

\begin{tabular}{|c|c|}
\hline Module (mm) & 4 \\
\hline Pressure angle (deg) & 20 \\
\hline Number of teeth & 40 \\
\hline Face width (mm) & 20 \\
\hline Pitch circle diameter (mm) & 160 \\
\hline Amount of addendum modification & 0 \\
\hline
\end{tabular}

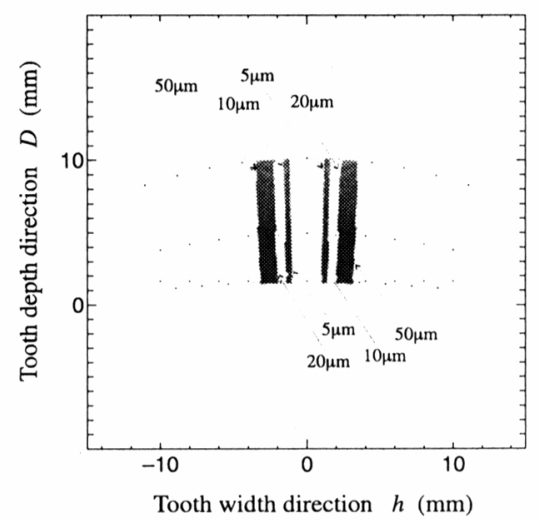

Fig. 9 Equi-gap contact pattern $\left(R=38 \mathrm{~mm}, \delta=0^{\circ}\right)$

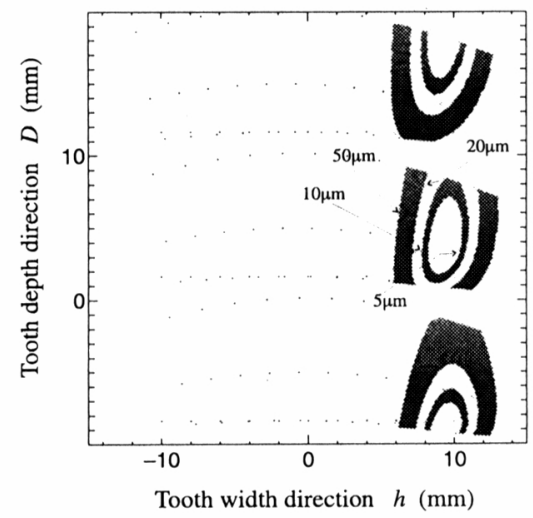

Fig. 10 Equi-gap contact pattern $\left(R=38 \mathrm{~mm}, \delta=5^{\circ}\right)$

リュート曲面であり,この平行曲面と外歯車歯面が点 接触しあう形態となる。これらの歯面同士の点接触位 置は, 歯面が最も食い込む位置, $\Delta$ が最小となる位置 として求まる。軸角変動用歯面隙間は, 全周歯におけ る歯面同士食い込み量の最大值 $\left(-\Delta_{\min }\right)$ に対応してい る、全周歯については, 式(9)(10)の $\theta_{1}, \theta_{2}$ をそれ ぞれの歯のピッチ角づつ回転させれば求まる. 実際に は, 表歯面, 裏歯面でそれぞれ $\left(-\Delta_{\min }\right)$ の隙間が必要 であり, 軸角変動用隙間 $C_{n}$ は $\left(-2 \Delta_{\min }\right)$ として与えら れる。 


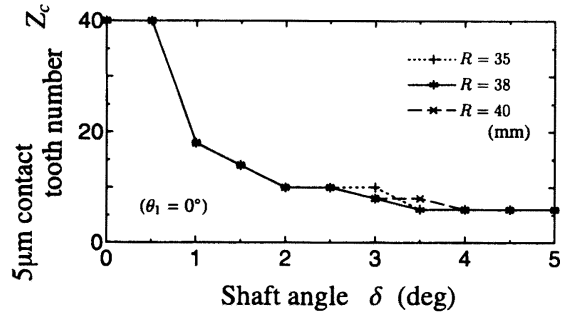

Fig. 11 Contact tooth number

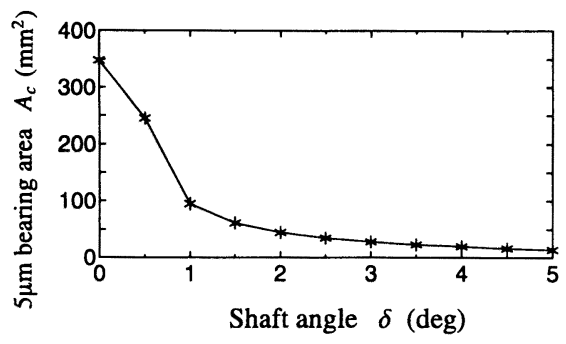

Fig. $125 \mu \mathrm{m}$ bearing area $A_{c}(R=38 \mathrm{~mm})$

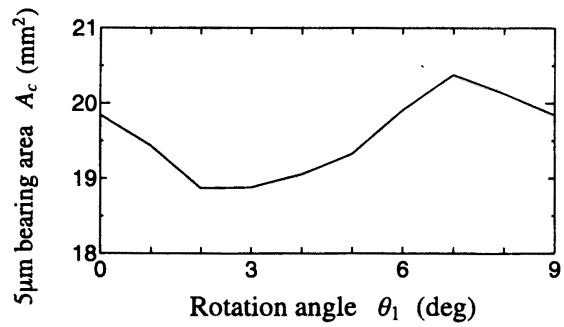

Fig. 13 Transition of bearing area on rotation of one tooth pitch $\left(R=38 \mathrm{~mm}, \delta=4^{\circ}\right)$

Table $25 \mu \mathrm{m}$ bearing area $A_{c}\left(\mathrm{~mm}^{2}\right)$

\begin{tabular}{|c|c|c|c|}
\hline$\delta$ & \multicolumn{3}{|c|}{$R(\mathrm{~mm})$} \\
\cline { 2 - 4 } & 35 & 38 & 40 \\
\hline $0^{\circ}$ & 328.1 & 347.8 & 353.0 \\
\hline $3^{\circ}$ & 28.2 & 28.1 & 28.1 \\
\hline $5^{\circ}$ & 14.1 & 13.8 & 10.2 \\
\hline
\end{tabular}

\section{4 数值計算例 数值例で用いるパラメータを} 表 1 に示す.

図 9 及び 10 に歯すじ曲率半径 $R=38(\mathrm{~mm})$ の場合 の軸角 $\delta$ が $0^{\circ}$ および $5^{\circ}$ における歯面等隙間パター ンを示す. 図 10 は歯車の回転における歯面等隙間パ ターンの推移である．まず, 図 10 上のように歯先部 で接触する．そしてピッチ角分回転した後のパターン が図 10 中であり，さらに回転し図 10 下のように歯元 部で接触する. $5 \mu \mathrm{m}$ 菌当たりに注目すると,

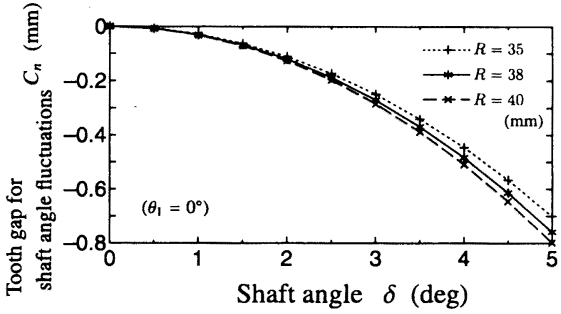

Fig. 14 Tooth gap for shaft angle fluctuation

- 歯車形継手における $5 \mu \mathrm{m}$ 歯当たりは, $\delta=0^{\circ}$ で は，歯たけ方向に長く伸びる.

・軸角が大きくなると歯幅端に移る.

- 歯面隙間ゼロ位置（接触点）は，歯車の回転に伴 い, 歯たけ方向に移動する.

高井ら ${ }^{(1)}$ の報告では，軸角にかかわらず，軸角 $0^{\circ}$ の場 合のような $5 \mu \mathrm{m}$ 歯当たりを仮定しているが，軸角 $5^{\circ}$ 程度に大きくなると， $5 \mu \mathrm{m}$ 歯当たりパターンは従来の 仮定とは大きく異なり, 点接触が生じているとした接 触評価をしなければならないことが分かる.

図 11 に $5 \mu \mathrm{m}$ かみ合い歯数 $Z_{\text {c }}$ を示す. 軸角が $1^{\circ}$ で 急激に少なくなっているが, 歯すじ曲率半径の影響は 小さいことがわかる.

図 12 に歯すじ曲率半径を $R=38(\mathrm{~mm})$ とした場合 のそれぞれの軸角 $\delta$ における $5 \mu \mathrm{m}$ 歯当たり面積 $A_{\text {，を }}$ 示寸. 軸角 $1^{\circ}$ で $5 \mu \mathrm{m}$ 歯当たり面積 $A_{c}$ が急激に減少 していることがわかる。これは図 11 から分かるよう に $5 \mu \mathrm{m}$ かみ合い歯数 $Z_{\mathrm{c}}$ が軸角 $1^{\circ}$ で約半分となるた めである. また, 最大軸角で $5 \mu \mathrm{m}$ 歯当たり面積 $A_{c}$ が 最小になる。

図 13 には歯のピッチ角分の回転の $5 \mu \mathrm{m}$ 歯当たり面 積 $A_{c}$. の変化を示す. 歯車を回転させると $5 \mu \mathrm{m}$ 歯当た り面積 $A_{c}$ は， $5 \%$ 程度は変動すると考えておかなけれ ばならない。

表 2 に歯すじの曲率半径を変えたときの $5 \mu \mathrm{m}$ 歯当 たり面積 $A_{c}$ をを示す. 歯すじ曲率半径が大きい程, 軸 角増大に伴う $5 \mu \mathrm{m}$ 歯当たり面積 $A_{c}$ の減少幅が大きい ことがわかる。

図 14 に軸角変動用歯面隙間量 $C_{n}$ と軸角 $\delta$ の関係 を示す. 歯すじの曲率半径が $R=38(\mathrm{~mm})$ については, 軸角 $5^{\circ}$ の位置で利用する場合には, 軸角変動用歯面 隙間 $C_{n}$ は約 $0.76 \mathrm{~mm}$ 必要であることがわかる. 加工 精度への配慮だけでなく, 理論的にも大きな軸角変動 用歯面隙間 $C_{n}$ が必要であることが分かる.

また, 歯すじ曲率半径 $R$ を小さくすると軸角変動用 歯面隙間 $C_{n}$ はわずかながら小さくなることがわかる. 


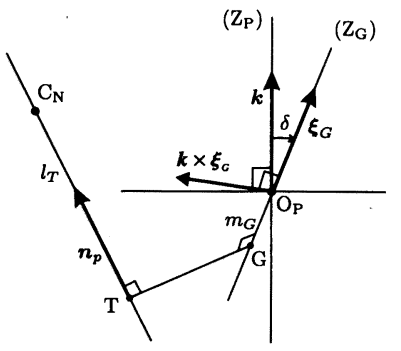

Fig. 15 The contact tooth normal related to the internal gear axis and the external gear axis

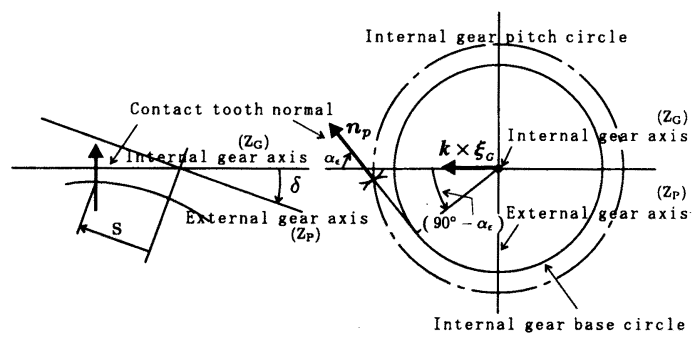

Fig. 16 Pose of the contact tooth normal against to the internal gear axis and the base circle

\section{4. 歯面の接触法線}

本章では，運動学的解析によって，歯面の点接触位 置の変化と, 前章までの歯面隙間解析結果とが整合す るかを検証することにした。

内歯車軸 $\mathrm{Z}_{\mathrm{G}}$, 外歯車軸 $\mathrm{Z}_{\mathrm{P}}$, 両車軸の共通垂線 $\boldsymbol{k} \times \boldsymbol{\xi}_{G}$, 歯面の接触法線 $\boldsymbol{n}_{P}$ の位置, 姿勢などの関係を図 15,16 に示す. 両車軸の共通垂線に垂直な平面一の接触法線 の投影位置を示す距離 $s$, および内歯車軸に垂直な平 面への投影姿勢を示す角度 $\left(90^{\circ}-\alpha_{\epsilon}\right)$ の二つの量によっ て接触法線の位置を表す.

解析の詳細は付録に示す。

図 17 に歯すじの円弧半径 $R$ をパラメータとし, 中 心からの距離 $s$ に対する $\delta$ と $\left(90^{\circ}-\alpha_{\epsilon}\right)$ の関係を示す. 内歯車軸方向への射影で見るとき, 接触法線は, 円弧 半径 $R$ が小さくなると， $\left(90^{\circ}-\alpha_{\epsilon}\right)$ が急激に大きくな る.このことは, 歯面の点接触位置が両車軸の共通垂 線上の柬面上の点から離れることであり，歯面の点接 触位置が変化するという歯面の隙間解析結果とも整合 している.

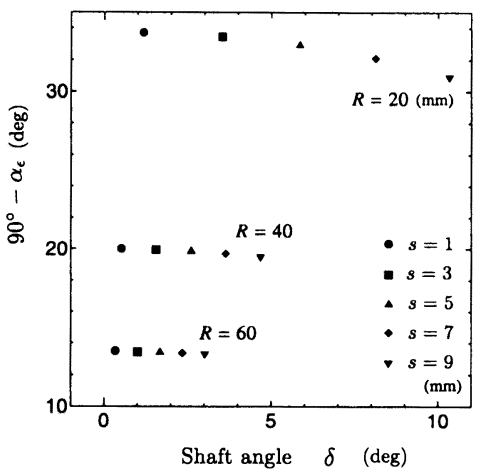

Fig. 17 Inclination angle $\alpha_{\epsilon}$ of contact tooth normal related to the shaft angle $\delta$ and the radius $R$ of rack tooth trace curve

\section{5. 結言}

平面ラックを円筒状に丸めたような円筒形のラック により外歯車が創成されこれとインボリュート内歯 車がかみ合うとして解析した結果，

1. 従来の歯面負荷強度計算では $5 \mu \mathrm{m}$ 歯当たりは, 円 筒と平面の接触のように，軸角によらず歯たけ方 向に一様な接触幅でのびているとされていた。し かし, 解析の結果, 軸角が $5^{\circ}$ 程度になると, 球 面と平面の接触に近い $5 \mu \mathrm{m}$ 当たりとなることが 分かった.

2. $5 \mu \mathrm{m}$ かみ合い歯数 $Z_{c}$ は, 軸角が大きくなると, $1^{\circ}$ から $2^{\circ}$ で急激に小さくなり，しだいに一定值に 近づく．また， $5 \mu \mathrm{m}$ かみ合い歯数 $Z_{c}$ に対する歯 すじ曲率の影響は小さい。

3. 軸角変動用歯面隙間 $C_{n}$ は, 軸角に対して二亲関 数的に大きくなり，ピッチ円直径が約 $160 \mathrm{~mm} の$ 継手に対して, 軸角が $5^{\circ}$ では $0.7 \mathrm{~mm}$ から $0.8 \mathrm{~mm}$ 程度となり，加工精度への配慮だけでなく，理論 的にも大きな軸角変動用歯面隙間 $C_{n}$ が必要であ ることが分かった。

4. インボリュート系の歯面を持つ歯車形継手では, 空間に固定された一直線上で両歯面が点接触する. その直線（接触歯面法線と一致）の位置を解析し た結果，軸角や歯すじ曲率により，その位置は変 化し，一定でないことが分かった。

\section{文献}

（1）高井昭, 斎田伸幸, 保延誠, 高西忠司, 日立評論,42$8,(1960), 54-59$ 
付

録

歯面隙間の数值解析の結果, 内歯車軸方向に投影し た歯面の点接触位置は両車軸の共通垂線の近傍にある が，軸角を変化させると，その位置も変化することが 注目された。そこで，運動学的解析によって，歯面の 点接触位置の変化と, 前章までの歯面隙間解析結果と が整合するかを検証することにした。

内歯車軸, 外歯車軸, 両車軸の共通垂線, 接触法線 の関係を示す図 15,16 において, 内歯車軸と外歯車軸 の共通垂線 $\boldsymbol{k} \times \boldsymbol{\xi}_{i}$ に対する接触法線 $\boldsymbol{n}_{P}$ の傾き $\alpha_{\epsilon}$ に ついて考える。

内歯車歯面を創成するラックを内歯車・ラック, 章 2 に示した外歯車を創成するラックを円筒ラック, さ らに内歯車・ラックのような平らな形状のラックを平 ラックと, 便宜上, 呼ぶことにする. 以下では, 内歯 車・ラックと平ラックは同形であるとする. また, 内 歯車・ラックと平ラックには, 左右両側面の歯面があ るが，そのうちの片側にのみ注目する.さらに，力の バランスに注意すれば分かるように，また現実にもそ うであるが, 内歯車軸と外歯車軸は交わりあっている.

図 3 の上図は円筒ラックの歯すじに垂直な断面 $\mathrm{X}_{\mathrm{RSO}}$ $\mathrm{Y}_{\mathrm{RSO}}$ のラック歯形線 (CL) を示すが, この線 (CL) で 円筒ラック歯面と接触する平ラック歯面を考えること ができる. 内歯車軸に対して外歯車軸が $\delta$ 傾いた位直 で, ラックの片側歯面に注目すると, 隣り合う平面状 歯面の間隔は一定であるので, 平ラック歯面を内歯車・ ラック歯面に重ね合わせること出来る. 平ラックと円 筒ラックの接触線 (CL) 上の歯面で外歯車歯面を創成 するとき，歯面の接触法線は $\mathrm{X}_{\mathrm{RSO}}-\mathrm{Y}_{\mathrm{RSO} O}$ 平面内にあり， しかも外歯車と内歯車の相対運動の瞬間軸 C を通る. 平ラック歯面法線方向はラックが並進運動しても空間 内では一定であるから，接触法線は一本であり，しか も空間内に固定される.

原点 $\mathrm{O}_{\mathrm{p}}$ で内歯車軸 $\boldsymbol{\xi}_{G}\left(\mathrm{Z}_{\mathrm{G}}\right)$ と外歯車軸 $\boldsymbol{k}\left(\mathrm{Z}_{\mathrm{p}}\right)$ は交わ るものとする.

接触法線と両歯車軸の位置関係を求めることにする. 解析は外歯車の解析に用いた座標系内で考えることに する. 先ず，外歯車歯面について考える. 図 4 におい て，面法線は $\boldsymbol{n}_{p}$ は以下のように表される。

$$
\boldsymbol{n}_{p}=\cos \beta \sin \alpha \boldsymbol{i}-\cos \alpha \boldsymbol{j}+\sin \beta \sin \alpha \boldsymbol{k}
$$

図 15 において内歯車歯面が接触条件を満たすには 法線が，内歯車の基礎円筒と接する必要があり，その 接点を $\mathrm{T}$ とする. ピッチ点 $\mathrm{C}_{\mathrm{N}}$ から点 $\mathrm{T}$ までの距離を $l_{T}$ とし, 原点 $\mathrm{O}_{\mathrm{p}}$ から点 $\mathrm{T}$ に向かうべクトルは

$$
\overrightarrow{\mathrm{O}_{\mathrm{P}} \mathrm{T}}=\overrightarrow{\mathrm{O}_{\mathrm{P}} \mathrm{C}_{\mathrm{N}}}-l_{T} \boldsymbol{n}_{P}
$$

$$
\overrightarrow{\mathrm{O}_{\mid \mathrm{P}]} \mathrm{C}_{\mathrm{N}}}=b \boldsymbol{i}+\left\{s-\left(\xi-R+\sqrt{R^{2}-s^{2}}\right) \tan \beta\right\} \boldsymbol{k}
$$

また， $\boldsymbol{n}_{p}$ は内歯車の面法線でもあるから

$$
\boldsymbol{\xi}_{\text {(i }} \cdot \boldsymbol{n}_{,}=0
$$

この条件を満たすように $\boldsymbol{\xi}_{\mathrm{i}}$ を, 変数 $\gamma$ を用いて次の ように表しておく.

$$
\boldsymbol{A}=\boldsymbol{k} \times \boldsymbol{n}_{p} / \sqrt{\left(\boldsymbol{k} \times \boldsymbol{n}_{p}\right)^{2}}
$$

として

$$
\boldsymbol{\xi}_{i}=\mathrm{R}\left(\boldsymbol{n}_{p}, \gamma\right) \boldsymbol{A}
$$

点 $\mathrm{T}$ から内歯車軸に下ろした垂線の足を $\mathrm{G}$ とし，原 点 $\mathrm{O}_{1}$, からの距離を $m_{G}$ とする. このとき距離 $\mathrm{GT}$ は内 歯車の基礎半径 $r_{G}$ である.

$$
\overrightarrow{\mathrm{GT}}^{2}=\left(\overrightarrow{\mathrm{O}_{p} \mathrm{C}_{\mathrm{N}}}-l_{r} \boldsymbol{n}_{p}-m_{G} \boldsymbol{\xi}_{G_{i}}\right)^{2}=r_{G}^{2}
$$

また，

$$
\overrightarrow{\mathrm{GT}} \cdot \boldsymbol{\xi}_{G}=0, \overrightarrow{\mathrm{GT}} \cdot \boldsymbol{n}_{p}=0, \boldsymbol{n}_{r} \cdot \boldsymbol{\xi}_{G_{i}}=0
$$

より,

$$
l_{T}=\left(\boldsymbol{n}_{p} \cdot \overrightarrow{\mathrm{O}_{\mathrm{p}} \mathrm{C}_{\mathrm{N}}}\right), m_{G}=\left(\boldsymbol{\xi}_{G} \cdot \overrightarrow{\mathrm{O}_{\mathrm{p}} \mathrm{C}_{\mathrm{N}}}\right) .
$$

従って, 式(29)より

$$
\begin{aligned}
\left(\boldsymbol{\xi}_{i} \cdot \overrightarrow{\mathrm{O}_{\mathrm{P}} \mathrm{C}_{\mathrm{N}}}\right) & = \pm \sqrt{\overrightarrow{\mathrm{O}_{1} \mathrm{C}_{\mathrm{N}}^{2}}-\left(\boldsymbol{n}_{p} \cdot \overrightarrow{\mathrm{O}_{\mathrm{P}} \mathrm{C}_{\mathrm{N}}}\right)^{2}-r_{G}^{2}} \\
& \equiv C_{C}
\end{aligned}
$$

$\boldsymbol{\xi}_{G}$ が変数 $\gamma$ を用いて式 (29)のように表されるので, 式 (20)の形の式が得られる.いま,

$$
\begin{gathered}
A \sin \gamma+B \cos \gamma+C=0 \\
A \equiv\left(\overrightarrow{\mathrm{O}_{P} \mathrm{C}_{\mathrm{N}}} \cdot \boldsymbol{n}_{p} \times \boldsymbol{A}\right) \\
B \equiv\left(\overrightarrow{\mathrm{O}_{\mathrm{P}} \mathrm{C}_{\mathrm{N}}} \cdot\left\{\boldsymbol{A}-\left(\boldsymbol{A} \cdot \boldsymbol{n}_{p}\right) \boldsymbol{n}_{p}\right\}\right) \\
C \equiv\left(\overrightarrow{\mathrm{O}_{\mathrm{P}}-C_{\mathrm{N}}} \cdot \boldsymbol{n}_{P}\right)\left(\boldsymbol{A} \cdot \boldsymbol{n}_{p}\right)-C_{C}
\end{gathered}
$$

とすると, 式 (21) の関係から $\gamma$ を求めることが出来 る.これを式 (29) に代入しすれば， $\boldsymbol{\xi}_{\text {G }}$ が定まる.

内歯車軸と外歯車軸の成寸角 $\delta$ は

$$
\cos \delta=\left(\boldsymbol{\xi}_{i} \cdot \boldsymbol{k}\right)
$$

また，図 16 において両車軸の共通垂線 $\boldsymbol{k} \times \boldsymbol{\xi}_{\mathrm{g}}$ に対す る接触法線 $\boldsymbol{n}_{P}$ の傾き $\alpha_{\boldsymbol{\epsilon}}$ は

$$
\cos \alpha_{\boldsymbol{\epsilon}}=\left(\boldsymbol{n}_{r} \cdot \boldsymbol{k} \times \boldsymbol{\xi}_{i} / \sqrt{\boldsymbol{k} \cdot \boldsymbol{\xi}_{i}}\right)
$$

で与えられる。 